\title{
Treatment of central precocious puberty with an intranasal analogue of GnRH (Buserelin)
}

\author{
J.P. Bourguignon ${ }^{1}$, G. Van Vliet ${ }^{2}$, M. Vandeweghe ${ }^{3}$, P.Malvaux ${ }^{4}$, M. Vanderschueren-Lodeweyckx ${ }^{5}$, \\ M.Craen ${ }^{6}$, M.V.L.Du Caju ${ }^{7}$, and C. Ernould ${ }^{1}$
}

\author{
${ }^{1}$ Department of Pediatrics, University of Liege, CHU du Sart Tilman, B-4000 Liege, Belgium \\ ${ }^{2}$ Department of Pediatrics, University of Brussels, Brussels, Belgium \\ ${ }^{3}$ Department of Endocrinology, University of Ghent, Ghent, Belgium \\ ${ }^{4}$ Department of Pediatrics, University of Louvain, Louvain, Belgium \\ ${ }^{5}$ Department of Pediatrics, University of Leuven, Leuven, Belgium \\ ${ }^{6}$ Department of Pediatrics, University of Ghent, Ghent, Belgium \\ ${ }^{7}$ Department of Pediatrics, University of Antwerpen, Antwerpen, Belgium
}

\begin{abstract}
One boy and 13 girls with central precocious puberty were treated for 1 year using Buserelin, a GnRH analogue, given intranasally $(0.3 \mathrm{mg}$, four times a day). After 1,3 and 12 months of therapy, the gonadotropin responses to GnRH were abolished in all the patients whereas mean basal serum concentrations of luteinizing hormone $(\mathrm{LH})$ remained similar to those of pubertal controls. During Buserelin treatment, genital development in the boy and breast development in the girls showed no further progress or some regression. In the boy, serum testosterone levels returned to prepubertal values. In the girls, serum oestradiol levels were variable and, in four of them, vaginal smears showed the persistence of a slight oestrogenic effect during therapy. Pelvic ultrasonography did not show any significant variation in ovarian and uterine lengths. Among the 14 patients, 3 had some progression of pubic hair development, irrespective of serum dehydroepiandrosterone sulphate (DHEAS) levels. In eight patients previously treated with cyproterone, elevated prolactin levels were observed before and during the first month of Buserelin administration. During treatment, mean height velocity was markedly reduced from 11.6 to $6.1 \mathrm{~cm} /$ year and mean bone age velocity $( \pm 1 \mathrm{SD})$ was $0.85 \pm 0.38$ year/year. After 1 year of treatment, the differences in predicted adult height ranged between -0.74 and +1.04 SDS (standard deviation score). These differences were inversely related $(r=-0.72)$ to the prognosis of adult height calculated before treatment. We conclude that, in central precocious puberty, intranasal administration of Buserelin, $1.2 \mathrm{mg} /$ day, may arrest sexual development and reduce height velocity and bone maturation. Improvement of adult height prognosis may occur, especially when it was markedly impaired before treatment.
\end{abstract}

Offprint requests to: J.P. Bourguignon

Abbreviations: $\mathrm{GnRH}=$ gonadotropin releasing hormone; $\mathrm{FSH}$ $=$ follicle stimulating hormone; $\mathrm{LH}=$ luteinizing hormone; SDS $=$ standard deviation score $;$ DHEAS $=$ dehydroepiandrosterone sulphate
Key words: Buserelin - Gonadotropin-releasing hormone analogue - Precocious puberty - Growth

\section{Introduction}

The pulsatile nature of GnRH release from the hypothalamus modulates pituitary responsiveness, since variations in $\mathrm{GnRH}$ pulse frequency induce different patterns of gonadotropin release $[13,25]$. In monkeys as in man, continuous or frequent pulsatile ( $>1$ pulse/h) administration of synthetic GnRH ultimately suppresses the release of FSH and LH in response to GnRH [2]. Such desensitization of the pituitary receptivity to GnRH may also be reversibly induced using superactive agonists of $\mathrm{GnRH}$, after a transient stimulatory effect $[27,36]$. Therefore, GnRH analogues offer a new possibility in the treatment of disorders associated with an undesirable activation of the pituitary gonadal axis, such as in central precocious puberty $[12,33,47]$. The interest in this new therapy was reinforced by the unsatisfactory control of growth and bone maturation using medroxyprogesterone or cyproterone $[3,22,23$, 45]. This paper reports on the clinical, biochemical and auxological data obtained throughout a 1-year period of intranasal administration of Buserelin, a GnRH agonist, in 14 patients with central precocious puberty.

\section{Patients and methods}

\section{Patients}

One boy and 13 girls with central precocious puberty were studied. Table 1 summarizes clinical data obtained from each patient at the time of diagnosis and at the initiation of treatment with Buserelin. The boy and 7 out of 13 girls had been treated previously with cyproterone acetate (mean dosage of about $100 \mathrm{mg} / \mathrm{m}^{2}$ per day). In these patients, cyproterone was discontinued 1 week before the initial endocrine evaluation. 
Table 1. Clinical data on patients with central precocious puberty before treatment using Buserelin

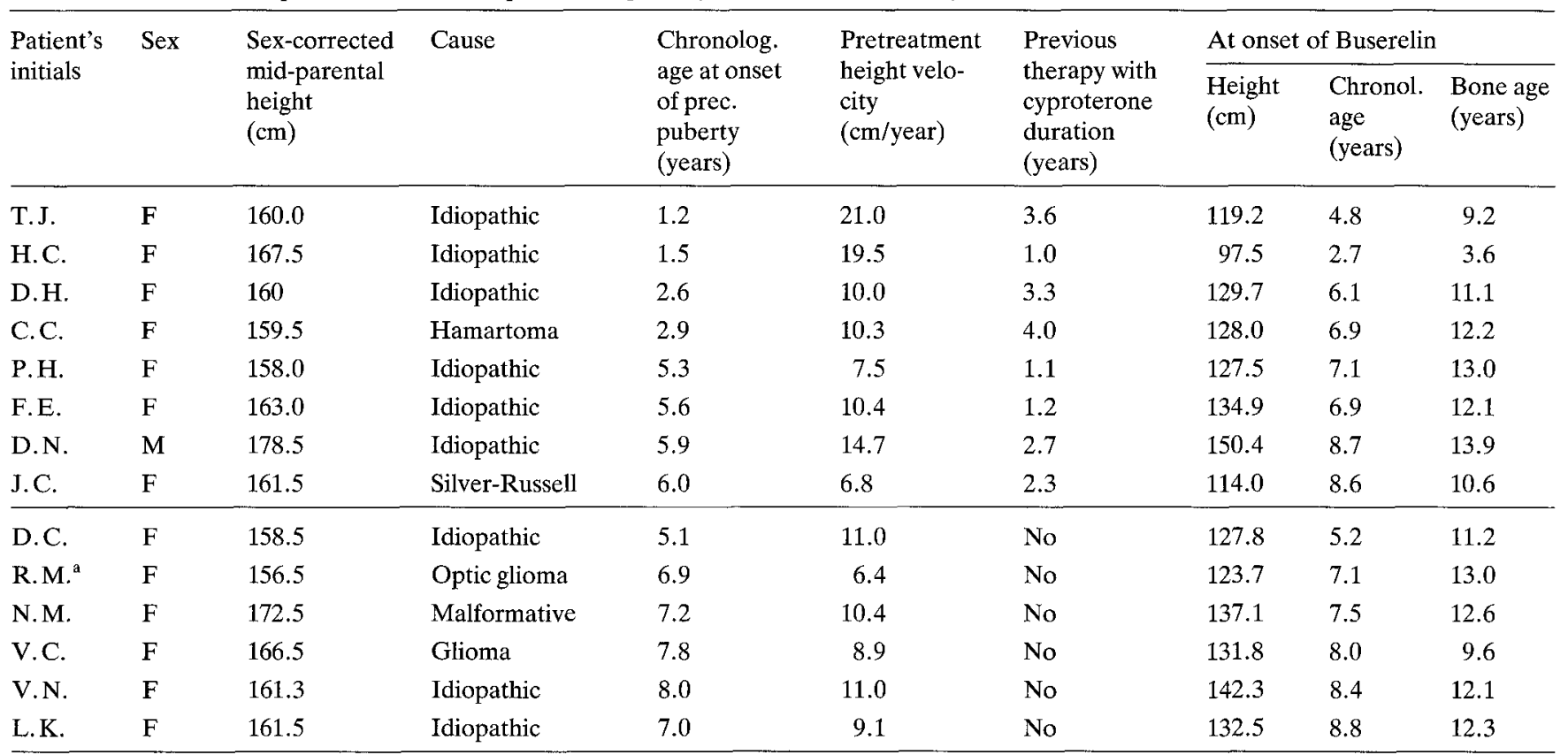

${ }^{a} \mathrm{GH}$ deficiency

Although a period off treatment longer than 1 week might be required before recovery of normal hormonal secretion, this was not evaluated for ethical reasons. Also, these patients received cyproterone during the first 2 weeks of Buserelin treatment, to avoid further development of clinical signs of puberty due to the initial and transient stimulatory effect [24].

Buserelin was generously provided by Dr.M. Delire (Hoechst, Belgium) as a nasal spray, each puff delivering $150 \mu \mathrm{g}$ of the peptide. The medication was stored at $4^{\circ} \mathrm{C}$ and administered as one puff in each nostril four times a day, around $8.00,12.00,16.00$ and $20.00 \mathrm{~h}$, amounting to a total daily dose of $1.2 \mathrm{mg}$. The mean daily dose ( $\pm 1 \mathrm{SD}$ ) of Buserelin was $42 \pm 15 \mu \mathrm{g} / \mathrm{kg}$. One girl (VN) was not compliant and stopped before the 6th month of therapy. Therefore, data were obtained only for 3 months in this patient.

\section{Methods}

The patients underwent a complete physical examination before and at $0.5,1,2,3,6,9$ and 12 months during treatment. Height was measured using a wall-mounted stadiometer. Genital development in the boy, breast development in the girls and pubic hair development in both sexes were evaluated according to the five stages of Tanner [40]. A morning blood sample was obtained at each visit except at 2 months. Single determinations of serum oestradiol concentrations in girls, testosterone in the boy, dehydroepiandrosterone sulphate (DHEAS) and prolactin in both sexes were obtained by radioimmunoassays. FSH and LH were measured basally and after stimulation with synthetic GnRH $25 \mu \mathrm{g} / \mathrm{m}^{2} \mathrm{IV}$, as previously described [6]. The presence of anti-GnRH IgG was investigated by a 5-day incubation of serial dilutions of the patient's serum with radiolabelled $\mathrm{GnRH}$ and subsequent separation of the free from the bound fraction using charcoal adsorption [5]. Bone age was evaluated before treatment and every 6 months, according to Greulich and Pyle [17] and according to Tanner et al., TW2, rating 20 bones of hand and wrist [43]. The former method was only used in order to calculate adult height prognosis using the method of Bayley and Pinneau [1].

The estimations of bone age were made by a single examiner (MV). Finally, a vaginal smear and a pelvic ultrasonography were obtained before treatment and after 1, 3 and 12 months. The vaginal smears were scored according to the presence of basal and parabasal cells only (stage I), predominant intermediate cells without superficial cells (stage II) or with superficial cells (stage III). From ultrasonographic data, the uterine length and the ovarian lengths were calculated. Using the growth standards of Tanner et al. [41], height age and height for bone age (SDS, standard deviation score) were calculated. The mean sex-corrected mid-parental height was also calculated [42]. For growth studies, the growth hormone deficient patient (RM) has been excluded. Statistical significance was calculated using Student's $t$-test, a difference being significant at a $P$ value $<0.05$.

\section{Results}

\section{Gonadotropin secretion (Fig. 1)}

In girls, as shown in Fig. 1, basal gonadotropin levels and their responses to GnRH showed a pubertal pattern of secretion before treatment. During Buserelin treatment, mean basal FSH was significantly lowered $(P<0.05)$ compared to the pretreatment level, whereas mean basal $\mathrm{LH}$ did not change and remained significantly higher than in prepubertal controls $(P<0.05)$. After 1,3 and 12 months of therapy, the responses of FSH and LH to GnRH were abolished. Similar data (not shown) were obtained in the boy.

\section{Physical development of puberty}

and serum sex steroid concentrations (Fig. 2)

In the boy, as shown in the upper panel of Fig. 2, genital development did not progress during Buserelin treatment and 


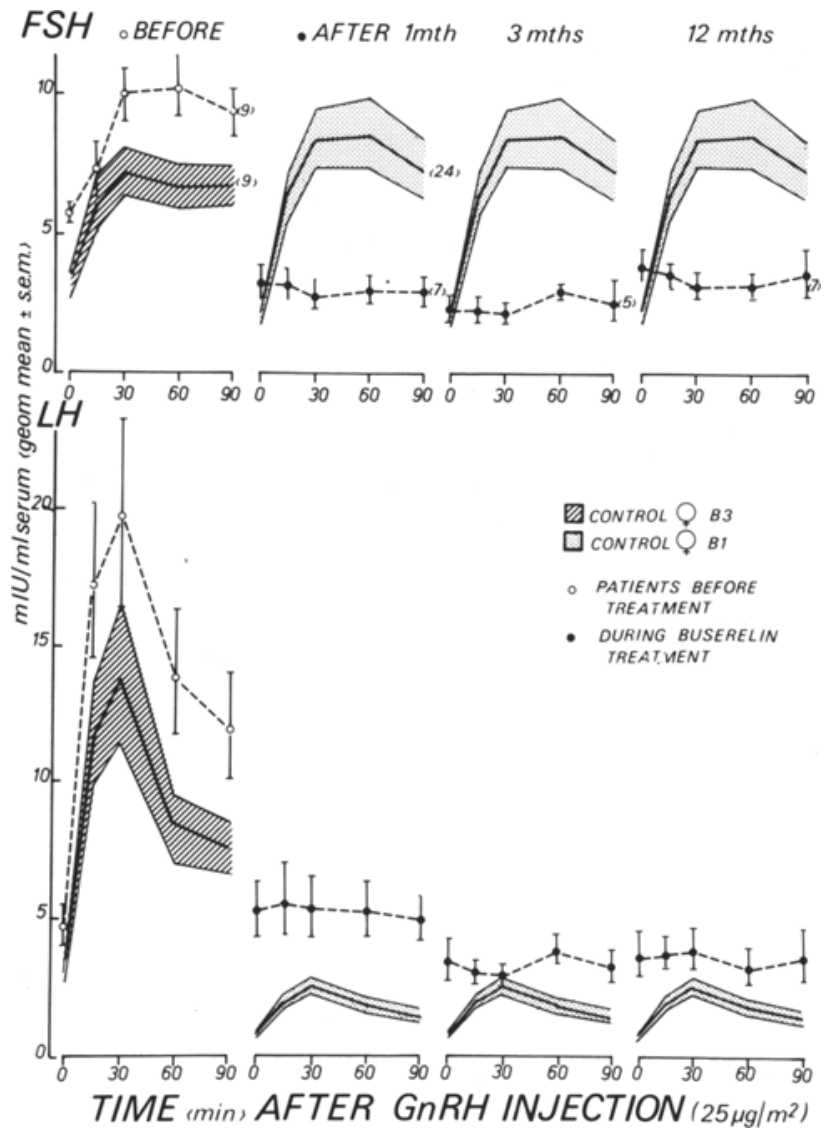

Fig.1. Mean ( \pm SEM) FSH (upper panel) and LH (lower panel) serum concentrations, basally and in response to $25 \mu \mathrm{g} / \mathrm{m}^{2}$ synthetic GnRH, in control girls and in girls with central precocious puberty, before and 1, 3 and 12 months during a treatment using a GnRH agonist, Buserelin, given intranasally. Values obtained before treatment are compared to those seen in pubertal controls whereas data obtained during the treatment are compared to those seen in prepubertal controls. The numbers of subjects or patients are indicated in brackets

serum testosterone levels returned to prepubertal values. In 10 out of 13 girls (Fig. 2, middle panel), breast development showed some regression during the treatment whereas it did not change in 3 girls. Although most serum oestradiol concentrations were in the prepubertal control range $(<20 \mathrm{pg} / \mathrm{ml})$ some increased values were observed at different times during the treatment. As shown in the lower panel of Fig. 2, pubic hair development did not change in most patients. Some degree of pubic hair development was observed in 9 out of 14 patients without relation to the serum concentrations of DHEAS, which were in the pre-adrenarcheal range $(<200 \mathrm{ng} / \mathrm{ml})$ in most patients. For all these parameters, no differences were observed between patients not treated previously and those treated with cyproterone.

\section{Serum prolactin levels (Fig. 3 )}

When compared to the patients not treated previously, those treated with cyproterone showed significantly higher serum prolactin levels 1 week after stopping cyproterone administration. A further rise in prolactin was seen after 2 weeks of combined administration of cyproterone and Buserelin whereas prolactin levels normalized progressively after withdrawal of cyproterone.
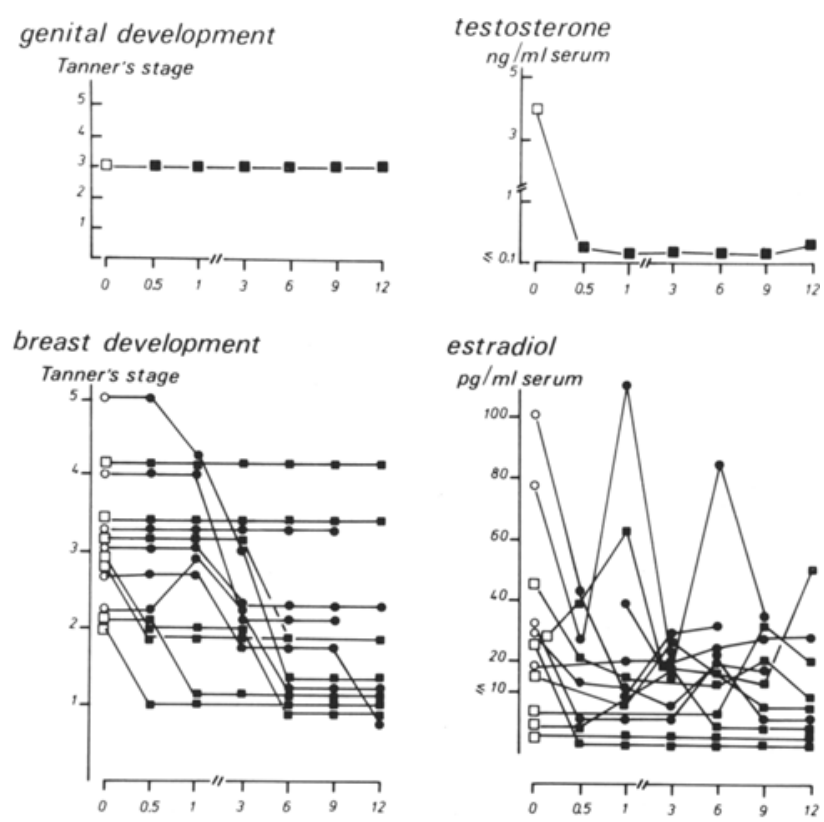

pubic hair develop.

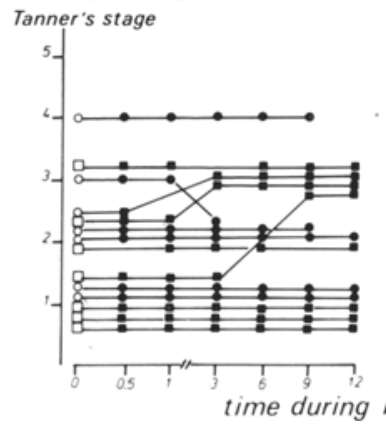

DHEA-S

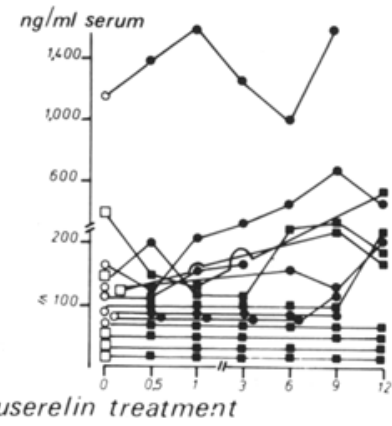

Fig. 2. Individual values of genital, breast and pubic hair development evaluated according to Tanner and testosterone, oestradiol and DHEAS serum concentrations before and during 1 year of intranasal Buserelin administration in patients with central precocious puberty $(O, \bullet=$ no previous treatment; $\square, \boldsymbol{\square}=$ treatment using cyproterone acetate before and during the first 2 weeks of Buserelin administration)

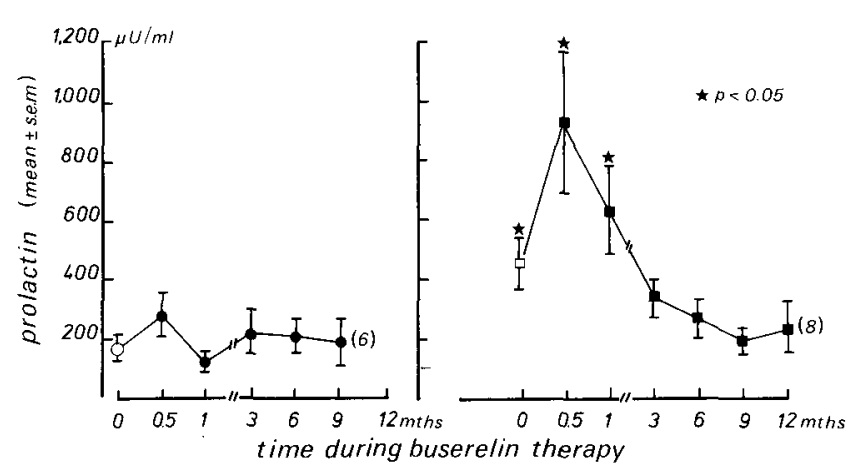

Fig. 3. Mean ( \pm Sem) serum levels of prolactin before and during Buserelin administration in patients with central precocious puberty either not treated previously $(\boldsymbol{Q}, n=6)$ or treated with cyproterone acetate before and during the first 2 weeks of Buserelin administration $(\boldsymbol{\square}, n=8)$. Asterisks denote significant differences between both groups of patients 


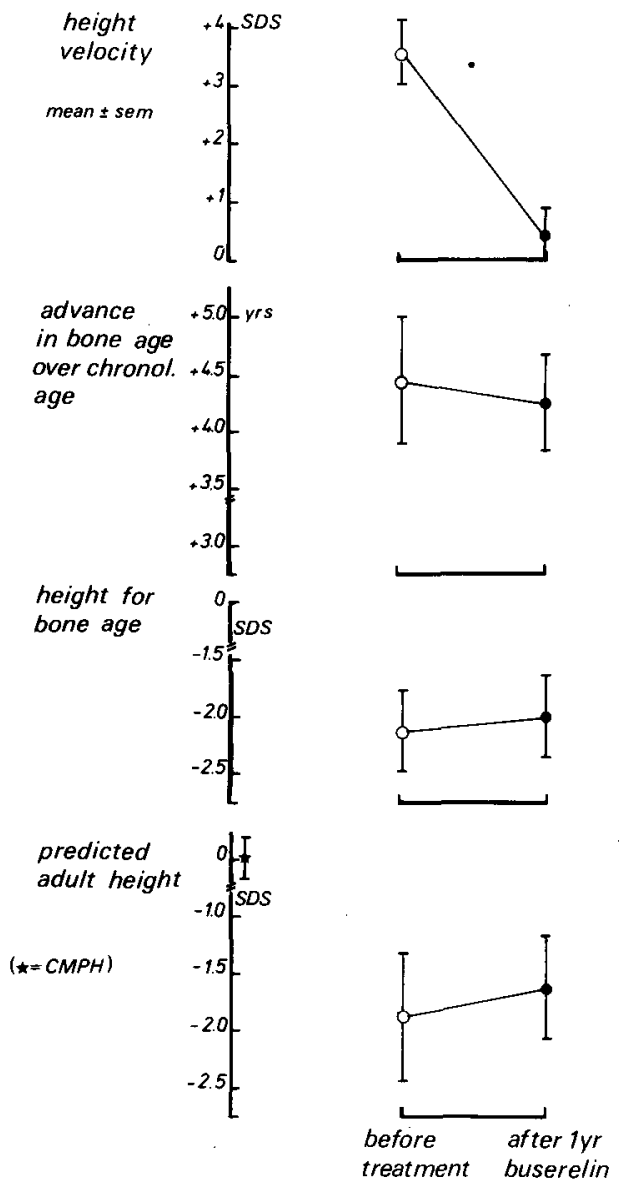

Fig. 4. Mean ( \pm Sem) standard deviation scores of velocity of height increase, height for bone age and predicted adult height and mean advance in bone age over chronological age before treatment and after 1 year of Buserelin administration. $\mathrm{CMPH}=$ sex-corrected mid-parental height

\section{Pelvic ultrasonography and vaginal smear}

In seven girls, mean uterine length $( \pm 1 \mathrm{SD})$ before the treatment and after 1,3 and 12 months was respectively $40 \pm 10$, $45 \pm 11,50 \pm 5$ and $47 \pm 7 \mathrm{~mm}$, no significant changes being observed. In six girls, mean ovarian length ( $\pm 1 \mathrm{SD})$ was similar before $(22 \pm 5 \mathrm{~mm})$ and after 1 year of treatment $(23 \pm$ $2 \mathrm{~mm}$ ) and no cysts were observed. Vaginal smears were studied in ten girls. Among five girls with signs of mild or strong oestrogenic activity observed before taking Buserelin or during the first 3 months of treatment, two subsequently showed a partial regression and three a total decrease of that hormonal effect. In two girls, signs of mild oestrogenic activity in vaginal epithelial cells persisted during the whole study. In three girls, vaginal smears did not show any oestrogenic effect except a transient moderate activity observed after 3 months in one patient.

\section{Growth and bone maturation}

As shown in Fig. 4, height velocity was increased (mean = +3.6 SDS) before treatment. Buserelin treatment resulted in a highly significant reduction $(P<0.001)$ in height velocity which was $6.1 \pm 1.6 \mathrm{~cm}$ (mean $\pm 1 \mathrm{SD}$ ) during the study. Before treatment, bone age was markedly advanced over chronological age (mean: +4.5 years). During 1 year of Buserelin

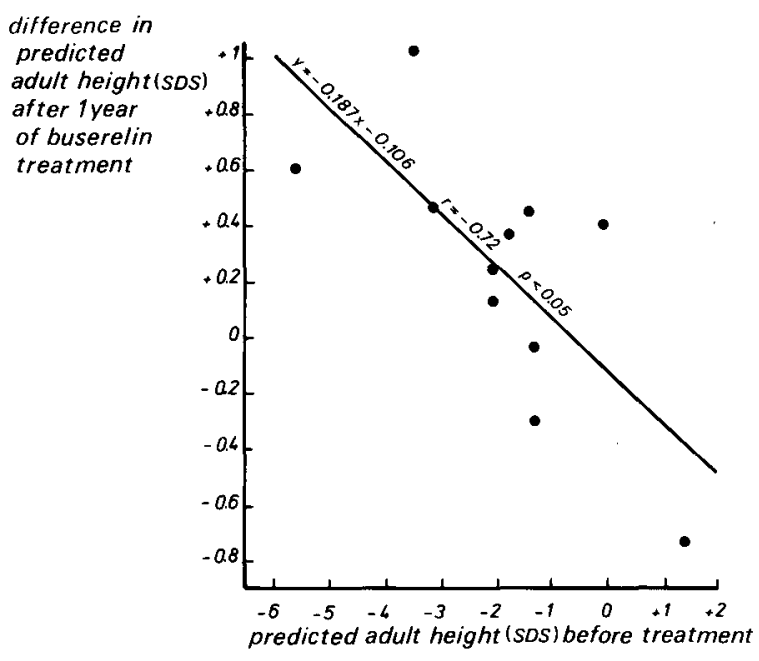

Fig. 5. Difference in predicted adult height (standard deviation score) after 1 year of Buserelin treatment for central precocious puberty, in relation to the adult height prognosis calculated before treatment

treatment, bone age increment varied between 0.1 and 1.4 years, (mean: 0.85 years). This normalized velocity of bone maturation accounts for the slight decrease $(-0.2$ years) of the mean advance in bone age over chronological age. The progression of height velocity and bone maturation were not significantly different during the first and the second 6-month periods of treatment (data not shown). Mean height for bone age had decreased to a mean value of -2.1 SDS before the treatment and was stabilized at -2.0 SDS after 1 year of treatment. Before precocious puberty, predicted adult height was expected to be normal. This was consistent with the mean ( $\pm 1 \mathrm{SD}$ ) sex-corrected mid-parental height found to be $0 \pm$ 0.5 SDS. Before treatment, predicted adult height varied between -5.6 and +1.5 SDS (mean: -1.88 SDS). After 1 year of Buserelin treatment, the mean predicted adult height was -1.64 SDS. The difference in predicted adult height calculated after 1 year of treatment ranged from -0.74 to +1.04 SDS. Individual data analysed in relation to predicted adult height calculated before therapy show an inverse linear correlation (Fig. 5). The major improvement was observed in the patients with the greatest impairment of predicted adult height before therapy.

\section{Side effects}

The only side effect was the occurrence of withdrawal bleeding in 6 out of 13 girls, between 0.5 and 3 months of therapy. No anti-GnRH antibodies could be detected in the patients' sera obtained at any time throughout the study.

\section{Discussion}

Highly potent analogues of GnRH have been proposed recently for the treatment of central precocious puberty $(4,8$, $26,28,32,38,39]$. Our data confirm the effectiveness of these analogues in normalizing height velocity and bone maturation. In addition, we provide evidence for a relationship between the impairment of final height prognosis before treatment and its improvement after 1 year of Buserelin treatment. Studies performed using Buserelin intranasally $[26,38]$ emphasize the importance of the dosage given. One-third of the patients treated by Luder et al. and Stanhope et al. [26, 38] showed 
progression of breast or genital development during therapy. In contrast, using a Buserelin dosage about twice as great as those authors, we have observed regression or arrest of pubertal development in all of our patients. These clinical observations emphasize the role of the dosage of the agonist using the intranasal route, in agreement with the experimental dose response studies in rats and dogs $[19,34]$ and in adult man [37]. The poor intranasal absorption (less than 5\%) of GnRH [5] and its agonist, Buserelin [20,30] probably accounts for the particular importance of the dosage using the intranasal route. Although serum Buserelin concentrations achieved after intranasal administration are several times lower than after subcutaneous injection of a similar dose [20,30], we found that a daily intranasal dose of $1200 \mu \mathrm{g}$ Buserelin, not associated with cyproterone, could be effective in initiating the inhibition of pituitary-gonadal function. During long-term administration of $\mathrm{GnRH}$ agonists, gonadotropin responses to a single injection of GnRH [4, 26, 28, 32, 38, 39] or to pulsatile administration of $\mathrm{GnRH}[14]$ as well as spontaneous pulsatile LH secretion [28, 38, 39] are abolished. However, our data and other observations on serum sex steroid levels [26] and vaginal smears $[8,28]$ suggest that the inhibitory effect is incomplete in some patients. Evans et al. demonstrated that a 48-h infusion of LH resulted in an increased testosterone secretion despite GnRH analog therapy [14]. Accordingly, the persistence of basal LH serum levels in the pubertal control range during the treatment with $\mathrm{GnRH}$ agonist $[26,28,38]$ might account for the partial inhibition of the pituitary gonadal axis. Although we used a highly specific radioimmunoassay for the measurement of FSH and $\mathrm{LH}$, we cannot exclude the possible presence of some immunoreactive fractions of the gonadotropins occurring during the treatment. A direct gonadal action of GnRH agonists is a matter of controversy since GnRH binding sites have been identified in rat gonadal tissue $[10,21,29]$ but not definitely in human gonads $[7,11]$. Sex steroid secretion is not likely to be affected through such receptors since Buserelin does not change testosterone response to $\mathrm{HCG}$ or $\mathrm{LH}$ in men $[14,35]$. Poor compliance was an obvious reason for incomplete suppression of sex steroids in a girl who stopped treatment after 3 months. Our data confirm that GnRH agonist therapy does not counteract adrenarche $[26,28,38,39]$ whereas cyproterone inhibits adrenal function $[3,23]$. In addition, we show that hyperprolactinaemia induced by cyproterone $[15,16]$ does not occur during GnRH agonist administration. So far, no antibodies against the native decapeptide or the agonists of GnRH could be detected in patients treated for precocious puberty [26, 28, 39]. Long-term studies are required for the evaluation of other possible side effects and psychological correlates of $\mathrm{GnRH}$ agonist treatment.

A normalization of height velocity during $\mathrm{GnRH}$ agonist treatment has been reported by all investigators $[4,8,26,28$, 32, 38, 39] except Kauli et al. [24] who combined cyproterone and the agonist in order to control the excessive growth rate of their patients. The reduction in height velocity during $\mathrm{GnRH}$ agonist treatment has been related to inhibition of growth hormone and somatomedin $\mathrm{C}$ secretion $[18,31]$. Adrenal androgens were suggested to account for differences in height velocity between patients treated with a GnRH agonist [46]. In several studies $[8,28,39] \mathrm{GnRH}$ agonists were shown to result in a dramatic deceleration in bone maturation with reference to the Greulich and Pyle standards [17]. As other authors [26, 38], we preferred the method of Tanner et al. [42], because of its accuracy. We showed that, at least during the first year of Buserelin therapy, bone age velocity was below 1 year/year in most patients whereas a rapid rate of skeletal maturation, above 1 year/year, has been described during normal puberty [9]. Since bone ages were rated according to the TW2 method [43] in our patients, predicted adult height was tentatively calculated with the TW mark II equations [44]. In agreement with Zachmann et al. [48], we found that this method resulted in a marked over-estimation of final height in precocious puberty. Therefore, we used the Bayley-Pinneau tables [1] and showed some improvement of final height prognosis. There was a great variation in predicted adult height. Our data suggest that the improvement is greatest in patients showing the major impairment of predicted adult height before therapy. Since individual reponses to the treatment were variable and since predicted adult height may differ from actual adult height, additional follow-up is required before definite conclusions are drawn.

Our observations indicate that Buserelin, like other agonists of $\mathrm{GnRH}$, may represent the first treatment available to control effectively growth and bone maturation in patients with central precocious puberty. Although the inhibitory effect was shown to be reversible, a long-term follow-up is still required to establish the benefit for adult height and to confirm the absence of side effects. Therefore, this treatment should be proposed only according to strict criteria based on psychological and auxological consequences of precocious puberty.

Acknowledgements. We are indebted to Dr. M. Delire (Hoechst Belgium) for his support of this study. We are grateful to Mrs. M. Beyer, B. Libion and S. Christian for their assistance in preparing the manuscript and the illustrations.

\section{References}

1. Bayley N, Pinneau SR (1952) Tables predicting adult height from skeletal age: Revised for use with Greulich-Pyle hand standards. J Pediatr 40: 423-441

2. Belchetz PE, Plant TM, Nakai Y, Keogh EJ, Knobil E (1978) Hypophysial responses to continuous and intermittent delivery of hypothalamic gonadotropin releasing hormone. Science 202:631633

3. Bierich JR (1975) Sexual precocity. Clin Endocrinol Metab 4:107

4. Boepple PA, Mansfield MJ, Wierman ME, Rudlin CR, Bode HH, Crigler JF, Crawford JD, Crowley WF (1986) Use of a potent, long-acting agonist of gonadotropin releasing hormone in the treatment of precocious puberty. Endocr Rev 7:24-33

5. Bourguignon JP, Burger HG, Franchimont $\mathbf{P}$ (1974) Radioimmunoassay of serum luteinizing hormone-releasing hormone ( $\mathrm{LH}-$ RH) after intranasal administration and evaluation of the pituitary gonadotrophic response. Clin Endocrinol 3:437-440

6. Bourguignon JP, Vanderschueren-Lodeweyckx M, Malvaux $\mathrm{P}$, Craen M, Du Caju MVL, Ernould C, Franchimont P (1982) Hypopituitarism and idiopathic delayed puberty: a longitudinal study in an attempt to diagnose gonadotropin deficiency before puberty. $J$ Clin Endocrinol Metab 54:733-744

7. Bramley TA, Menzies GS, Baird DT (1985) Specific binding of gonadotropin releasing hormone and an agonist to human corpus luteum homogenates: characterization, properties and luteal phase levels. J Clin Endocrinol Metab 61:834-841

8. Brauner R, Thibaud E, Bischof P, Sizonenko PC, Rappaport R (1985) Long-term results of GnRH analogue (Buserelin) treatment in girls with central precocious puberty. Acta Pediatr Scand $74: 945-951$

9. Buckler JMH (1984) Skeletal age changes in puberty. Arch Dis Child 59:115-119 
10. Clayton RN, Harwood JP, Catt KJ (1979) Gonadotropin releasing hormone analogue binds to luteal cells and inhibits progesterone production. Nature 282:90-92

11. Clayton RN, Huhtaniemi IT (1982) Absence of gonadotropin releasing hormone receptors in human gonadal tissue. Nature 299: $56-59$

12. Crowley WF, Comite F, Vale W, Rivier J, Loriaux DL, Cutler GB (1981) Therapeutic use of pituitary desensitization with a long acting LHRH agonist: a potential new treatment for idiopathic precocious puberty. J Clin Endocrinol Metab 52:370-372

13. Crowley WF, Filicori M, Spratt DI, Santoro NF (1985) The physiology of gonadotropin releasing hormone $(\mathrm{GnRH})$ secretion in men and women. Recent Prog Horm Res 41:473-531

14. Evans RM, Doelle GC, Alexander AN, Uderman HD, Rabin D (1984) Gonadotropin and steroid secretory patterns during chronic treatment with a luteinizing hormone-releasing hormone agonist analog in men. J Clin Endocrinol Metab 58:862-867

15. Fonzo D, Angeli A, Sivieri R, Andriolo S, Frajria R, Cesera F (1977) Hyperprolactinemia in girls with idiopathic precocious puberty under prolonged treatment with cyproterone acetate. J Clin Endocrinol Metab 45:164-168

16. Graf KJ, Schmidt-Gollwitzer M, Koch UJ, Lorenz F, Hammerstein J (1978) Hyperprolactinemia induced by cyproterone acetate in human subjects. J Endocrinol Invest [Suppl 215] 87:96

17. Greulich WW, Pyle SI (1959) Radiographic atlas of skeletal development of the hand and wrist, 2nd edn. Stanford University Press, Stanford

18. Harris DA, Van Vliet G, Egli CA, Grumbach MM, Kaplan SL, Styne DM, Vainsel M (1985) Somatomedin C in normal puberty and in true precocious puberty before and after treatment with a potent luteinizing hormone-releasing hormone agonist. J Clin Endocrinol Metab 61:152-159

19. Heather JD, Whitehead SA (1985) Changes in pituitary responsiveness to LH-releasing hormone after acute Buserelin treatment: a time-course and dose-dependent study. J Endocrinol 106: $27-30$

20. Holland FJ, Fishman L, Costigan DC, Luna L, Leeder S (1986) Pharmacokinetic characteristics of the gonadotropin-releasing hormone analog D-ser-(TBU) ${ }^{6}-\mathrm{EA}^{10}$ luteinizing hormone-releasing hormone (Buserelin) after subcutaneous and intranasal admidnistration in children with central precocious puberty. J Clin Endocrinol Metab 63:1065-1070

21. Hsueh AJW, Jones PBC (1981) Extra-pituitary actions of gonadotropin releasing hormone. Endocr Rev 2:437-452

22. Kauli R, Pertzelan A, Prager-Lewin R, Grunebau M, Laron Z (1976) Cyproterone acetate in treatment of precocious puberty. Arch Dis Child 51:202-208

23. Kauli R, Pertzelan A, Ben Zeev Z, Prager-Lewin R, Kaufman H, Comaru Schally AM, Schally AV, Laron Z (1984) Treatment of precocious puberty with LHRH analogue in combination with cyproterone acetate. Further experience. Clin Endocrinol 20: 377-387

24. Knobil E (1980) The neuroendocrine control of the menstrual cycle. Recent Prog Horm Res 36:53-88

25. Lee PA (1981) Medroxyprogesterone therapy for sexual precocity in girls. Am J Dis Child 135:443-447

26. Luder AS, Holland FJ, Costigan DC, Jenner MR, Wielgosz G, Fazekas ATA (1984) Intranasal and subcutaneous treatment of central precocious puberty in both sexes with a long-acting analog of luteinizing hormone-releasing hormone. J Clin Endocrinol Metab 58:966-972

27. Mann DR, Gould KH, Collins DC (1984) Influence of continuous gonadotropin-releasing hormone ( $\mathrm{GnRH})$ agonist treatment on litteinizing hormone and testosterone secretion, the response to GnRH, and the testicular response to human chorionic gonadotropin in male rhesus monkeys. J Clin Endocrinol Metab 58:262-267

28. Mansfield MJ, Beardsworth DE, Loughlin JS, Crawford JD, Bode HH, Rivier J, Vale W, Kushner DC, Crigler JF, Crowley WF (1983) Long-term treatment of central precocious puberty with a long-acting analogue of luteinizing hormone-releasing hormone. Effects on somatic growth and skeletal maturation. N Engl J Med 309:1286-1290

29. Pieper DR, Richards JS, Marshall JC (1981) Ovarian gonadotropin releasing hormone $(\mathrm{GnRH})$ receptors: characterization, dis- tribution and induction by GnRH. Endocrinology 108:1148-1155 30. Reznik Y, Winiger BP, Aubert ML, Sizonenko PC (1984) Pharmacodynamics of $\left[\right.$ Desgly $\left.{ }^{10}, \mathrm{D}-\mathrm{Ser}(\mathrm{t}-\mathrm{Bu})^{6}\right]$-GnRH-EA in 6 normal volunteers and in 2 girls with precocious puberty. Pediatr Res $182: 1210$ (abstr)

31. Rudlin CR, Mansfield MJ, Crigler JF, Karol KA, Crawford JD, Boepple PA, Crowley WF (1985) Decrease in growth hormone and somatomedin C during LHRH agonist treatment of central precocious puberty. Pediatr Res 19:633 (abstr)

32. Roger M, Chaussain JL, Berlier P, Bost M, Canlorbe P, Colle M, Francois R, Garandeau P, Lahlou N, Morel Y, Schally AV (1986) Long-term treatment of male and female precocious puberty by periodic administration of a long-acting preparation of D-TRP luteinizing hormone-releasing hormone microcapsules. J Clin Endocrinol Metab 62:670-677

33. Sandow J (1983) Clinical applications of LHRH and its analogues. Clin Endocrinol 18:571-592

34. Sandow J, Rechenberg WV, Baeder C, Engelbart K (1980) Antifertility effects of an LHRH analogue in male rats and dogs. Int $\mathrm{J}$ Fertil 25:213-221

35. Schaison G, Brailly S, Vuagnat P, Bouchard P, Milgrom E (1984) Absence of direct inhibitory effect of the GnRH D-Ser (TBU) ${ }^{6}$, Desgly-NH2 ${ }^{10}$ GnRH ethylamide (Buserelin) on testicular steroidogenesis in men. J Clin Endocrinol Metab 58:885-890

36. Schurmeyer TH, Knuth UA, Freischem CW, Sandow J, Bint Akhtar F, Nieschlag E (1984) Suppression of pituitary and testicular function in normal men by constant gonadotropin-releasing hormone agonist infusion. J Clin Endocrinol Metab 59:19-24

37. Smith R, Donald RA, Espiner EA, Stronach S (1979) The effects of prolonged administration of D-SER (TBU) ${ }^{6}$-LHRH-EA ${ }^{10}$ (HOE 766) in subjects with hypogonadotropic hypogonadism. Clin Endocrinol 11:553-559

38. Stanhope R, Adams J, Brook CGD (1985) The treatment of central precocious puberty using an intranasal LHRH analogue (Buserelin). Clin Endocrinol 26:795-806

39. Styne DM, Harris DA, Egli CA, Conte FA, Kaplan SL, Rivier J, Vale W, Grumbach MM (1985) Treatment of true precocious puberty with a potent luteinizing hormone-releasing factor agonist: effect on growth, sexual maturation, pelvic sonography and the hypothalamic-pituitary-gonadal axis. J Clin Endocrinol Metab 61: $142-151$

40. Tanner JM (1962) Growth at adolescence, 2nd ed. Blackwell, Oxford

41. Tanner JM, Whitehouse RH, Takaishi M (1965) Standards from birth to maturity for height, weight, height velocity and weight velocity: British children 1965. Arch Dis Child 41 :454-471

42. Tanner JM, Goldstein H, Whitehouse RH (1970) Standards for children's height at ages 2-9 years allowing for height of parents. Arch Dis Child 45:755-762

43. Tanner JM, Whitehouse RH, Marshall WA, Healy MJR, Goldstein $H$ (1975) Assessment of skeletal maturity and prediction of adult height. Academic Press, London New York

44. Tanner JM, Landt KW, Cameron N, Carter BS, Patel J (1983) Prediction of adult height from height and bone age in childhood. A new system of equations (TW mark II) based on a sample including very tall and very short children. Arch Dis Child 58:767776

45. Werder EA, Murset G, Zachmann M, Brook CGD, Prader A (1974) Treatment of precocious puberty with cyproterone acetate. Pediatr Res 8:248-255

46. Wierman ME, Beardsworth DE, Crawford JD, Crigler JF, Mansfield MJ, Bode HH, Boepple PA, Kushner DC, Crowley WF (1986) Adrenarche and skeletal maturation during luteinizing hormone releasing hormone analogue suppression of gonadarche. $J$ Clin Invest $77: 121-126$

47. Yen SSC (1983) Clinical applications of gonadotropin-releasing hormone and gonadotropin-releasing hormone analogs. Fertil Steril 39:257-266

48. Zachmann M, Sobradillo B, Frank M, Frisch H, Prader A (1978) Bayley-Pinneau, Roche-Wainer-Thissen, and Tanner height predictions in normal children and in patients with various pathologic conditions. J Pediatr 93:749-755

Received August 20, 1986 / Accepted March 10, 1987 